\title{
INJURY AS A CAUSE OF NEPHRECTOMIES IN THE REGIONAL ASPECT
}

\author{
N.O. Saidakova ${ }^{\text {, O.V. Shulyak }}{ }^{1}$, G.E. Kononova ${ }^{1}$, \\ V.I. Grodzinsky ${ }^{2}$, V.M. Shylo ${ }^{3}$

\section{${ }^{1}$ SI "Institute of Urology of the National Academy of Medical Sciences of Ukraine" \\ ${ }^{2}$ Ivano-Frankivsk Regional Clinical Hospital \\ ${ }^{3}$ Cherkasy Regional Hospital of Cherkasy Regional Council}

Introduction. Today, as in previous years, any cause of nephrectomy should not be ignored, especially in connection with the problem of single kidney disease with it $[1,2]$. Its relevance does not become less, even with the minimization of the risk of developing pathology in a single kidney, often the one that led to the removal of the contralateral. After all, as is known, the concept of "healthy single kidney" in urology is conditional, given the almost unambiguous opinion of the authors that "its functioning is carried out to the limit" [3, 4]. Every patient with a single kidney a priori belongs to the group of increased risk, because in fact doomed, regardless of time, to reduce its functional capacity, the development of chronic kidney disease in need of replacement therapy, and with it, deteriorating quality of life and reducing its duration $[5,6,7]$. Due to the lack in clinical practice of the ability to predict the risk of disease in a relatively "healthy kidney", it is promising to study the structure of the causes of nephrectomies. This approach, to some extent, will help guide the development of prevention tools. In information resources, cancer and kidney stones, the share of which was about $81 \%$, are widely considered as the causes of nephrectomies $[8,9]$.

The aim of this paper is to study the frequency of modern causes of organ-carrying operations with an emphasis on their dynamics and regional features of kidney injury, which is a relevant clinical practice in view of the above information.

Materials and methods. The work uses the data of the official institution. The study period was 10 years (2009-2018), with two five-year plans (2009-2013 and 2014-2018) in order to track not only the dynamics of the number of nephrectomies, including injuries, but and the intensity of process changes over the years. The comparative analysis was conducted in Ukraine as a whole and in its administrative territories. A special feature was the exclusion of data for 2009-2013 for the Autonomous Republic of Crimea and the city of
Sevastopol so that the results of the comparison were correct for the second period (2014-2018), for which they were absent. The nature of time series was assessed by absolute changes, growth rate (decrease) of indicators, as well as extensive coefficients, which were used to study the internal structure. If it was necessary to determine the reliability of the difference between the two statistical coefficients, the mean error and Student's t test were calculated.

Results and discussion. A comparative analysis of the total number of nephrectomies (NE) and the frequency of injuries that caused them over two periods of 5 years (2009-2013 and 2014-2018) revealed features that manifested both differences and similarities in the dynamics of the indicators. In particular, the first five years were characterized by an increase in the total number of transactions, resulting in 4,326 in 2013 , which is $5.2 \%$ more than in 2009. On average, $4260 \pm 37$ nephrectomies were performed annually. The second five-year period was marked by a decrease in such interventions by the same percentage (5.2\%) to 2926 in 2018 , and averaged $2990 \pm 25$, that is significantly less than in the previous period. The share of injuries in the structure of nephrectomies did not exceed $2.5 \%$ for all years. Each of the periods is characterized by its decrease over the years. During 2009-2013, it was consistently equal to $2.1 \% ; 2.4 \% ; 2.2 \%$ and $1.6 \%$ each in the last two years; during 2014$2018-2.3 \% ; 2.5 \% ; 2.3 \% ; 1.6 \%$ and $1.7 \%$. The proportion of injuries resulting in nephrectomy in the first 3 years of each five-year period was in the range of $2.1 \%-2.5 \%$, in the following decreased to $1.6 \%$ and $1.7 \%$. The rate of decrease was $21.8 \%$ and $28.6 \%$, respectively, for 2009-2013 and 20142018. Specific absolute values were as follows in 2013 - 68 transactions against 87 for five consecutive years, in $2018-50$ against 70 , respectively. On average, $84 \pm 6$ and $62 \pm 5$ nephrectomies were performed by periods, respectively. These data show that both the total average number of nephrectomies 
and those caused by their trauma probably decreased over the second five years. Of interest is the information on individual administrative territories. With the indisputable mosaic of cases of nephrectomies due to trauma, certain trends were observed that differed in periods. The first was characterized by a halving of areas in which there were no nephrectomies as a cause of injuries (in 2013 - 3 against 6 in 2009). The second - on the contrary, was characterized by four times more such areas (in 2018 - 8 against 2 in 2014). That is, there is a positive trend in the form of a smaller number of administrative territories in which the injury was the cause of organ removal.

The average values for the periods were $3 \pm 0.3$ and $4 \pm 0.5$, which indicates the reliability of these changes. The next feature was the frequency of injuries in the regional aspect. It turned out that during 2009-2013, the number of oblasts gradually increased, with 5 injuries leading to organ-extirpating surgery; their percentage was $52.0 \pm 11.4 \%$ and $68.0 \pm$ $11.3 \%(\mathrm{p}>0.05)$, respectively. At the same time, they decreased from 6 to 18 injuries: from $24.0 \%$ to $20 \%$, respectively. Attention is drawn to the second period, in which for 2014-2018, on the contrary, the number of oblasts with up to 5 injuries decreased, namely from $76.0 \pm 9.7 \%$ to $56.0 \pm 13.2 \%(\mathrm{p}>0,05)$ with practical stabilization in the range of $6-12$ ( $16 \%$ and $12 \%$ respectively). During the analysis of oblasts by the frequency of injuries leading to nephrectomies, for all their variability, it became possible to identify those that stand out among others. In the first five years, these included Dnipropetrovsk, Donetsk, Luhansk, Zaporizhia, Lviv (5 or more injuries per year).Three of them (Dni propetrovsk, Donetsk, Zaporizhia) continued to maintain their leading position; they were joined by Rivne and Odessa regions. As can be seen, the composition of these areas and the explanation of the situation are in the plane of the common mining and processing industry existing there.

Thus, the analysis of the situation in Ukraine as a whole shows a positive trend in the number of nephrectomies performed. Their increase during 2009-2013 (by 5.2\%) was replaced by a decrease of the same percentage in 2014-2018. The dynamics of the frequency of injuries as the causes of organremoving surgery should also be considered positive, the rate of their reduction was $21.8 \%$ and $28.6 \%$, respectively. This feature includes growth in the second period of oblasts with no such cause in the structure of nephrectomies. However, in contrast to the previous five-year plan, there was a reduction in the number of areas to 5 injuries, as well as those that draw attention to their frequency as the cause of nephrectomy throughout the years of study.

\section{Conclusions}

It was found that the total number of nephrectomies, in contrast to the previous five years, in 2014-2018 decreased by 5.2\% (to 2926) cases; in their structure the share of injuries did not exceed $2.5 \%$ all years and there was a characteristic decrease in each of the periods; on average, they accounted for $84 \pm 6$ and $62 \pm 5$, respectively, in 2009-2013 and 2014-2018.

The regional features of the frequency of injuries as the causes of nephrectomies were manifested by a change in the number of oblasts where it was absent, an increase in the second fiveyear period ( 2 and 4 times, respectively).

The number of oblasts with up to 5 injuries among the causes of nephrectomies decreases with the years of the second period (from $76.0 \%$ to $56.0 \%$, respectively, in 2014 and 2018), while in the first increased (from $52.0 \%$ to $68.0 \%$ ). The areas that stand out among others in terms of the number of injuries that led to organ-removing operations were identified.

\section{Список літератури}

1. Аляев Ю.Г., Глыбочко П.В., Григорян 3.Г., Газимиев М.А. Органосохраняющие операции при опухоли почки. Москва: ГЭОТАР Медиа, 2009. 272 с.

2. Банира О.Б., Строй О.О., Шуляк О.В. Аспекти діагностики та лікування малих ниркових новоутворень. Мед. аспекты здоровья мужчины. 2012. № 2. С. 42-51.

3. Бачурін В.Ї., Бачурін Г.В., Бачурін А.В., Міхно О.Ю. Онкологічна патологія в умовах невідкладної урологічної допомоги. Запорізький мед. журнал. 2012. № 5. С. 5-7.

4. Возіанов С.О., Банира О.Б., Шуляк О.В., Строй О.О., Шамраєв С.М., Шадьоркін Ї.А., Шеремета Р.3., Тарчинець М.В. Рак нирки. Львів: Кварт, 2011. 381 с.

5. Гусев А.А., Евсеев С.В., Коган М.И. Оценка почечных функций и оперативное лечение почечно-клеточного рака. Онкоурология. 2013. № 1. С. 17-23.

6. Переверзев А.С., Щукин Д.В., Щербак А.Ю. Органосохраняющие операции при почечноклеточном раке. Онкоурология. 2009. № 2. С. 22-30. 
7. Сайдакова Н.О., Старцева Л.М., Царенко В.Л., Гродзінський Ї.В., Ониськів О.О., Шевченко Г.А. Епідеміологія раку нирки в Україні. Здоровье мужчины. 2011. № 2. С. 164-172.

8. Серегин А.В., Лоран О.Б., Ашугян В.Р. Факторы прогноза выживаемости при раке почки. Онкоурология. 2009. № 2. С. 15-21.

9. Строй О.О., Литвинець Є.А., Банира О.Б., Шуляк О.В. Прогностичні фактори виживаності після нефректомій з приводу локалізованого раку нирки. Галицький лікарський вісник. 2012. № 19(3). С. 53-55.

10. Ljungberg B., Cowan N., Handury D.C. et al. Guidelines on Renal Cell Carcinoma. European Association of Urology, 2012. P. 36-39.

\section{References}

1. Ljungberg, B., Cowan, N., Handury, D.C., et al. (2012). Guidelines on Renal Cell Carcinoma. European Association of Urology.

\section{Реферат}

TPABMA, НЕФРЕКТОМЇЙ В РЕГІОНАЛЬНОМУ ACПЕКТI

Н.О. Сайдакова, О.В. Шуляк,

Г.Є. Кононова, В.Іे. Гродзінський,

В.М. Шило

Робота грунтується на матеріалах офіційної статистичної звітності і висвітлює питання динаміки нефректомій i, зокрема, травму нирки, як їі причину. Аналізуються дані за десять років (2009-2018 рр.), при цьому виділяються два п'ятирічних періоди, що дає можливість прослідити не тільки характер змін абсолютних показників за тривалий період, але й визначити їх інтенсивність за роками вивчення. Ситуація оцінювалась в цілому по Україні та в регіональному аспекті. Використана загальновідома система показників: абсолютний приріст (зменшення), темп приросту (зниження), екстенсивні коефіцієнти, за якими досліджувалась внутрішня структура. При необхідності визначення достовірності різниці двох параметрів розраховувався критерій Стьюдента. Встановлена позитивна тенденція у вигляді зменшення загальної кількості нефректомій за другий період, в цілому по УКраїні на 5,2\% до 2926 операцій у 2018 р., на відміну від попередньої п'ятирічки, коли спостерігалось їх збільшення (на 5,2\%) з 4110 до 4326 у 2013 році. Частка травм в структурі нефректомій не перевищувала 2,5\% усі роки вивчення. Для неї характерним було зменшення в кожному із періодів - темп його становив $21,8 \%$ та 28,6\% відповідно, в результаті чого кількість в середньому дорівнювала $84 \pm 6$ та $62 \pm 5$ операцій. Виявлені регіональні особливості за частотою травм. Відмінність проявилася збільшен-

\section{Реферат}

\begin{tabular}{l}
\multicolumn{1}{l}{ ТРАВМА, КАК } \\
НЕФРЭКТОМИЙ \\
АСПЕКТЕ
\end{tabular}

Н.А. Сайдакова, А.В. Шуляк,

Г.Е. Кононова, В.И. Гродзинский, В.Н. Шило

Работа основывается на материалах официальной статистической отчетности и освещает вопросы динамики нефрэктомий и, в частности, травму почки, как ее причину. Анализируются данные за десять лет (2009-2018 гг.), при этом выделяются два пятилетних периода. Это дает возможность проследить не только характер изменений абсолютных показателей за длительный период, но и определить их интенсивность по годам изучения. Ситуация оценивалась в целом по Украине и в региональном аспекте. Использована общеизвестная система показателей: абсолютный прирост (уменьшение), темп прироста (снижения), экстенсивные коэффициенты, по которым исследовалась внутренняя структура. При необходимости определения достоверности разницы двух параметров рассчитывался критерий Стьюдента. Установлена положительная тенденция в виде уменьшения общего количества нефрэктомий в целом по $\mathrm{У}_{\mathrm{K}-}$ раине на 5,2\% до 2926 операций в 2018 г. В отличие от предыдущей пятилетки, когда наблюдалось их увеличение (на 5,2\%) с 4110 до 4326 в 2013 году. Процент травм в структуре нефрэктомий не превышал 2,5\% все годы изучения. Для нее характерно уменьшение в каждом из периодов - темп его составлял $21,8 \%$ и $28,6 \%$ соответственно, в результате чего количество в среднем равнялась $84 \pm 6$ и $62 \pm 5$ операций. Выявлены региональные особенности по частоте 
ням у 4 рази до 8 областей за 2014-2018 рр., в яких не було жодної травми нирки, яка б призвела до органовиносних операцій, тоді як в попередні п’ять років, навпаки, відмічалось їх зменшення з 6 до 3. Разом з тим, кількість областей до 5 випадків на рік травм нирки, наслідком якої стала нефректомія, стало менше в останні 5 років (з 76,0\% до 56,0\%) проти їхньог зростання в минулі 5 років (з 52,0\% до 68,0\%). Виявлені області, що виділяються серед інших за числом травм. До них відносяться переважно ті, де розвинута гірничодобувна промисловість (Дніпропетровська, Донецька, Луганська, Львівська, Запорізька, Рівненська).

Ключові слова: нефректомія, травма нирки, органовиносні операції, регіони.

\section{Адреса для листування}

Н.О. Сайдакова

E-mail: urol.epid@gmail.com травм. Отличие проявилось увеличением в 4 раза до 8 областей за 2014-2018 гг., в которых не было ни одной травмы почки, приведших к органовыносящей операции, тогда как в предыдущие пять лет, наоборот, отмечалось их снижение с 6 до 3. Вместе с тем, количество областей до 5 случаев в год травм почки, следствием которой стала нефрэктомия, уменьшилось в последние 5 лет (с 76,0\% до 56,0\%) против их роста в прошедшее пятилетие (с 52,0\% до 68,0\%). Выявлены области, которые выделяются среди других по числу травм. К ним относятся в основном те, где развита горнодобывающая промышленность (Днепропетровская, Донецкая, Луганская, Львовская, Запорожская, Ровенская).

Ключевые слова: нефрэктомия, травма почки, органовыносящие операции, регионы. 